\title{
The land as a Leitmotiv in the book of Amos
}

S D Snyman

(University of the Free State)

\section{ABSTRACT}

\section{The land as a Leitmotiv in the book of Amos}

The hypothesis argued is that the theme of the land serves as a leitmotiv in the book of Amos. The focus of this investigation will be on the occurrence of the words normally used in connection with the land, that is eretz (אר The land is promised and granted (2:9-10; 3:2,9) to the people to live in and enjoy the produce the land yields but their stay in the land is not unconditional. Unfortunately, only a small part of the population shared in the wealth of the land. People that also ought to have shared in the bounty of the land, were exploited only to make the rich even richer and the poor even poorer. Consequently, the land would turn against the people living in and of it $11: 2 ; 4: 4-12$; $8: 4,8-9,11)$. Ultimately the land would be lost in exile $(3: 11,15$; $4: 1-3 ; 7: 10-17)$. At the end of the book it is foreseen that the land will once again be restored to the people (9:11-15). In light of the importance of the land in the book and the looming threat of a coming exile due to the conditions in the land, it is suggested that the reference to the earthquake in 1:2 may take on an additional metaphorical meaning. The reference to the earthquake is perhaps a premonition of what may be expected: turmoil and upheaval in the land and even expulsion from the land instead of peace and stability. Mentioning the earthquake right at the beginning may be a subtle reminder that the land is at stake in the prophecies that will follow in the rest of the book.

\section{INTRODUCTION}

It may be said that there is general agreement that the theme of the land in the Old Testament is an extremely important one. The subject is treated in books on the theology of the Old Testament (Von Rad 1975; Zimmerli 1972; Preuss 1991; Barth 1991; Gunneweg 1993; Albertz 1994; Brueggemann 1997; Rendtorff 2001). A number of monographs (Diepold 1972; Brueggemann 1977; Wright 1983, 1990; Weinfeld 1992; Habel 1995) have been published in recent years and there is a constant flow of other publications on this 
subject (von Rad 1984; Zimmerli 1976; Zenger 1993; Noort 1993; Noort 1998:12-28; Helberg 1999:273-289; Helberg 1999:567-583).

According to Brueggemann (1977:3) the issue of the land is "a central, if not the central theme of Biblical faith". Von Rad (1975:297) views the promise of the land as the distinguishing leitmotiv of the Hexateuch. The land is the last of Yahweh's redemptive acts in the credo of Deuteronomy 26:5-9. In an article on the land in the Hexateuch Von Rad says: "In the whole of the Hexateuch there is probably no more important idea than that expressed in terms of the land promised and granted by Yahweh..." (Von Rad 1984:79). The Hexateuch may be seen as the story of the land promised to Abraham in Genesis 12:1-3 up till the fulfilment of the promise in the book of Joshua (Jos 21:43-45). Noort (1998:12) once remarked: "The theme of the land belongs to the most important theological items of the Hebrew Bible".

What makes the land so important is the fact that almost every theological tradition in the Old Testament is in some way connected to the promise and granting of the land to the people of Israel (Noort 1993:4; Helberg 1999:274-278) and according to LaCocque (1996:93) the land is the sine qua non for the very existence of Israel. The tradition of the land can therefore not be isolated from other traditions in the Old Testament, as references to the land can be found in almost every tradition of Israel. Preuss (1991:119) remarked that the full arch of the Pentateuch tradition extends from the promise of the land, to the ancestors, to the Moses group, to Israel coming into existence, and to the realization that even these promises had found their fulfilment with the reaching and possession of the land. Rendtorff (2001:42) is in agreement with this when he remarked that the promise of the land and its fulfilment serves as the distinguishing element binding the different epochs of Israel's early history together.

The hypothesis argued in this paper is that the theme of the land serves as a leitmotiv in the book of Amos. It is argued that the gift of a land is an important theme running like a golden thread throughout the book. At the same time it is not suggested that this is the only or most important theme in the book. The book of Amos is multi-faceted and can be studied from a variety of viewpoints. By way of a careful scrutiny of the text of the book of Amos the thesis will be demonstrated. The focus of this investigation will be on the occurrence of the words normally used in connection with the land, 
that is אדמה may refer to the land in general, the land as territory, as an area with political boundaries, the earth or cosmos, whereas אדמה has the meaning of soil, ground, the actual dwelling place of human beings, agricultural soil, a civilized world (Preuss 1991:118). In the book of Amos these two terms occur quite frequently and function virtually as synonyms with ארץ as the more prominent term (twenty times but in three cases - 2:10;3:1 and 9:7 - the land of Egypt is mentioned; אדמה is mentioned nine times). That the two terms אדמה andion as synonyms can be seen throughout the book. It seems as if the two terms are used inter-changeably in the various units of the book. The much discussed part on the dispute between Amos and Amaziah in Amos 7:10-17 may serve as an example: The land (ארץ) cannot bear the words of Amos says verse 10 because he said that Israel will be taken into exile away from their land (אדמתר verse 11). Amaziah thereupon told Amos to go back to the land (ארץ) of Judah in verse 12. Amos responded with a prophecy informing Amaziah inter alia that his land (אדמה) will be measured and divided, while he will die in a pagan land (אדמה) with Israel going into exile away form their land (אדמתר) in verse 17.

\section{THE LAND GRANTED}

Amos 1:3 - 2:16 consists of a prophecy directed at six neighbouring countries, followed by a prophecy against Judah and finally culminating in an address to Israel itself. In Amos 2:9-10 the first explicit reference to the granting of the land (ארץ) to Israel is made:

"I destroyed the Amorite before them, though he was tall as the cedars and strong as the oaks. I destroyed his fruit above and his roots below. I brought you up out of Egypt, I led you forty years in the desert to give you the land of the Amorites" (NIV).

Note that the granting of the land is mentioned twice, once at the beginning and once at the end of the part dealing with Yahweh's redemptive acts in the history of Israel, creating an inclusio (Paul 1991:90; Strydom 1996:439) and thereby underlining the importance of the granting of the land (contra Wolff 1977:141-142 who regards verse 10 as a later addition). In addition to that, it is also clear that both the exodus and the wandering in the wilderness eventually lead to the conquest of the land by the strength of Yahweh. Thus, both the exodus and the wandering in the wilderness find its purpose and goal in the gift of the land (Rudolph 1971:146; Paul 1991:91; Niehaus 
1992:369). Without the gift of the land, the deliverance from Egypt and the wandering in the wilderness for a period of forty years would be meaningless. Van Leeuwen (1985:88) noted that by using the term העליתי the emphasis is on the purpose of the exodus: entering the land promised to them. To live in the land is nothing but a gift from Yahweh.

Amos 3:2 is an important text in the book of Amos. Jeremias (1995:32) made the remark that to understand the book of Amos one has to understand Amos 3:2! What makes Amos 3:2 relevant in this investigation is that the text refers to land or earth (האדמה): "You only I have known of all the families of the earth". A dominant line of interpretation is to link the phrase "all the families of the earth" with Genesis 12:3 and 28:14 connecting it with Abraham and Jacob (Rudolph 1971:153; Van der Woude 1997:41; Paul 1991:101; Van Leeuwen 1985:102) and thus indirectly with the promise of the land, but as Wolff $(1977: 177)$ rightly observes, there is no evidence that Amos was influenced by these passages from Genesis.

Attention also focused on the first part of the verse. In the context of the book of Amos, דיע ' may refer to any of the other main salvation traditions of Israel. It has long been established that the root ידע "used here has a wide variety of possible meanings such as "knowledge" or "to know" or "to know intimately" etcetera, leading בחר scholars to the conclusion that ידע serves as a synonym for meaning "to elect". That Yahweh knows Israel of all the families of the earth means that Yahweh elected them to be his people. Be it true, this will be a clear link with the events of the exodus. There is

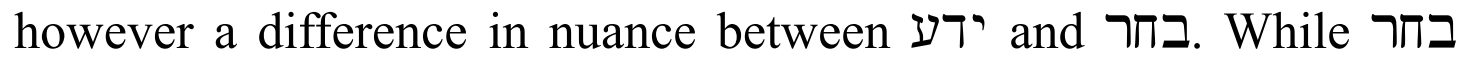
would indicate the origin of Yahweh's relation with Israel, בדעו is a term more likely to indicate a lasting and intimate relation over an extended period of time. Furthermore, the view Amos has on the exodus later in the book (9:7) makes this proposal improbable.

'די may also be interpreted as a covenant term linking up with the events at Sinai where Israel entered into a covenant with Yahweh so that the phrase at the beginning of verse may also be translated as: "Only you have I selected as my covenant partner" (Paul 1991:102). Wolff (1977:176-177) offered the possibility that ידע may be a reference to the granting of the land. According to him (1977:177), the way in which the giving of the land is contrasted in 2:9 with Israel's behaviour in 2:6-8 indicates that the giving of the land was supposed to have normative significance for Israel. In addition to 
this it might also be added that in 3:2 occurs almost verbatim in Deuteronomy 9:24: דעתי אתכם ירעם and in both cases God is subject of the verb. This verse is preceded in Deuteronomy 9:23 by a command from the Yahweh to go and take possession of the land $\mathrm{He}$ has given them so that a connection is created between the root ידע and the possession of the land. Moreover, the context of Deuteronomy 9:23-24 is that of Israel's sins of mistrust, disobedience and rebellious behaviour towards Yahweh in spite of which they were given the land. The thrust of Amos 3:2 is that Yahweh is about to punish Israel because they have been known to the Lord of all the families of the land, yet they did not live accordingly. Amos 3:2 echoes thus the sentiments already expressed in Deuteronomy 9:23-24 that Yahweh knew them, gave them the land and yet they rebelled against His commands by their mistrust and disobedience. It seems that Amos 3:2 brings the granting of the land to mind, rather than any other of the salvation traditions of Israel.

In Amos 3:9 there is yet another indicator of the land given to the people. The mentioning of Ashdod and Egypt alongside each other in Amos 3:9 gave rise to a number of proposals (Snyman 1994:559-562). Egypt is mentioned to alert the people to the events of the exodus. Ashdod serves as a subtle reminder of the conquest of the land. In Josua 12:22; 13:3 and 15:47 Ashdod is mentioned in connection with the conquest of the land. In Amos 3:9 Ashdod and Egypt are called upon as witnesses to the unrest and oppression in Samaria. The initial accusation of the prophet amounts to his verdict upon the affluent people of Samaria living in their strongholds. An (unnamed) enemy will come and surround the country pulling down their defences and ruining their fortresses (verse 11), in a word, they stand to loose the land granted to them by Yahweh during the time of the conquest of the land. The possible loss of the land thus stands over against the initial granting of the land alluded to by the mentioning of Ashdod at the beginning of the pericope.

\section{THE LAND LOST IN A COMING EXILE}

\subsection{The living conditions in the land}

Time and again it is said that the land Israel will enter is a good land. It is a land flowing with milk and honey (Ex 3:8, 17; 13:5; 33:3; Num 13:27; Deut 6:3; 11:9; 26:9; Jos 5:6 etc) indicating a land with vast possibilities in providing enough pasture for animals to provide 
milk and an abundance of produce produced from the fruitful soil. In Deut 8:7-10 the land is described as a land with streams and pools of water, with springs flowing in the valleys and the hills; a land with wheat and barley; vines and fig trees, pomegranates, olive oil and honey; a land where bread will not be scarce and where nobody will lack anything; a land with even minerals to be mined.

During the eighth century it seems as if all these promises made to the people were come to pass. According to Amos 1:1 the prophet delivered his prophesies when Jerobeam son of Jehoash was king of Israel $(787 / 6$ - 747/6). It was a time when there was little threat from neighbouring and foreign powers. The Aramean kingdom that launched several attacks on Israel during the last years of the ninth century was subdued by Assyria. Assyria itself was kept occupied by the kingdom of Urartu and had to suffer a period of weak kings. Israel and Judah enjoyed a period of peaceful relations. All this opened the door to Israel to expand its borders, territories east of the Jordan were annexed and the northern border reached as far as Lebo-Hamath (II Ki 14:25; Am 6:13-14). Major trade routes passing up and down Transjordan and into northern Arabia through Israelite territory paved the way for an economical revival far beyond the expectations of ordinary Israelites. Commerce and trade flourished, houses were build on a grand scale with some Israelites owning both a summer and winter house (Am 3:15), (let us remind ourselves that a home is part of the Hebrew view of the ties between a person and his land Koch 1983:47) these houses were luxuriously furnished decorated with ivory and in the houses they were feasting on the finest quality of food available - in short it was a time of peace and prosperity to be enjoyed by the people living off the rich produce of the land.

Unfortunately, only a small part of the population shared in the wealth of the land. There are numerous examples in the book of Amos where people who also ought to share in the bounty of the land, were exploited only to make the rich even richer and the poor even poorer. In Amos 2:6-7b one reads about the needy being sold for a pair of sandals; the poor were trampled upon and justice was denied to the oppressed. The same kind of injustices are echoed in Amos 5:7, 11-12 and 8:4. In 8:4 the poor is significantly called the poor of the land (ענוי ארץ).

According to Deuteronomic-Deuteronomistic theology there was no such thing as living unconditionally in the land. 
Deuteronomy-Deuteronomistic theology has many admonitions to the people not to forfeit the land by unduly behaviour. Needless to say that the commands do not only pertain to religious duties to be fulfilled however important they may be, but especially the way in which a neighbour is treated. So for instance, Deuteronomy 25:15 admonishes: "You must have accurate and honest weights and measures, so that you may live long in the land the Lord your God is giving you" (NIV). The commands given by Yahweh must be obeyed to live in the land. Alternatively, disobeying the commands of Yahweh will inevitably result in the curses mentioned in Deuteronomy that ultimately means the loss of the land.

\subsection{The land turning against the people}

\subsubsection{Amos 1:2}

It is a truism to say that Amos 1:2 is an important verse in the book. Many scholars view this text as the motto of the entire book (Hammerschaimb 1970:19, 21; Rudolph 1971:117; Weiser 1974: 132; Wolff 1977:119; Van Leeuwen 1985:45; Van der Woude 1997:20). The verse was the subject of intense investigation from many angles that cannot be repeated here, what is the concern of this paper is the second half of the verse: "the pastures of the shepherds dry up, and the top of the Carmel withers". There can be little doubt that the land is at stake here. The roar of Yahweh from Zion and the thunder from Jerusalem will show its effect on the land. The verbs used to describe the effect of Yahweh's judgment indicate drought and eventually devastation. The judgement of Yahweh is directed against the land - his own land (Rudolph 1971:117) only to result in its desiccation and complete devastation (Paul 1991:39-40; Wolff 1977:125). The land suffers but ultimately it will be the people living in the land who will suffer. When a land dries up as is predicted with its effect on both the pastureland as well as the lush of the Carmel forests, the very existence of the people is at stake. The threats made here is in full accordance with the threats and curses foreseen in the book of Deuteronomy 28:22-24 should Israel not comply to the stipulations and admonitions for living in the land of promise.

\subsubsection{Amos 4:4-12}

In Amos 4:4-12 the land as leitmotiv surfaces again. In an ironic way the people of Israel are invited to go to Bethel and Gilgal - both respected sanctuaries - to sin instead of worshipping Yahweh. Bethel is well known as a place of worship for Israel founded by Jerobeam I 
to counter Jerusalem as the central place of worship for the people of Yahweh. The cult was established for the gods who brought Israel up (1 Ki 12:28) out of Egypt, and according to Koch (1983:52), 'leading up' is a word indicating possession of the land of other people. Bethel has even deeper roots in the history of the people. It is also the place where Jacob had the dream of angels ascending and descending from heaven to earth, thus making it a place where Yahweh manifested his presence in a dramatic way. In the dream of Jacob God promised him the land: "I will give you and your descendants the land on which you are lying" (Gen 28:13). Bethel is thus unmistakeably linked to the promise of the land. Gilgal is also linked to the possession of the land. Gilgal was likewise an important cultic centre, but Gigal was also the very first stop after the people entered the land. It was a place where Joshua set up twelve stones as a remembrance to the event where Israel crossed the river Jordan on dry ground and entered the land of promise (Josh 4:19-23). Bethel and Gilgal represent therefore not only cultic places of worship, it would also bring back memories of the promise (Bethel) and the taking of the land, in the case of Gilgal. It is in this regard that Koch (1983:55) made the very apt remark that "it is precisely these cultic places which were connected with the gift of the land which Yahweh promised to the patriarchs in days of old, implementing his promise through the events of salvation history".

In 4:5-9 a series of catastrophes that befell the people is recorded. The people suffered famine (4:6); followed by drought (4:7-8); followed by blight, mildew and locusts destroying the crops the people hoped to harvest (4:9). All these catastrophes are related to the land. Instead of the blessings of bounty and fertility expected as promised to them when entering the land, the opposite has happened - they were struck by curses and maledictions (Paul 1991:141). Deuteronomy (28) tells the people what will happen when they do not obey the covenant stipulations; Amos told the people what had happened to them, implying that the ominous threats of the covenant curses already materialised (Paul 1991:143). The land promised to the people would be "a land with wheat and barley, vines and fig trees, pomegranates, olive oil and honey" (Deut $8: 8)$, but now the gardens and vineyards are struck with blight and mildew as foreseen in the curses predicted (in Deut 28:22), as well as locusts devouring the rich produce of the land (Van der Woude 1997:54; Niehaus 1992:399-400). 
In 4:10 the plagues of Egypt are recalled but with an important difference. The plagues of Egypt were performed and experienced on foreign soil in Egypt, now the plagues are applied to the people of Israel living in the land promised to them. The remainder of this part deals with threats of a military kind and does not have any direct bearing on the theme of the land. There is some difference of opinion on whether the reference to Sodom and Gomorrah should be interpreted as an earthquake or simply as a metaphor for the overturning of a kingdom by Yahweh. The latter interpretation is favoured in this contribution.

\subsubsection{Amos 7:1-3 and 7:4-6}

Amos 7:1-3 and 4-6 form part of the so-called visions of Amos stretching to Amos 8:1-3 but interrupted by the dispute between Amos and Amaziah the priest, in Amos 7:10-17.

In Amos 7:1-3 the land (ארץ) is threatened with a swarm of locusts, echoing Amos 4:9 where locusts were also named as a disaster. The difference between Amos 4:9 and 7:1-3 is that in the case of 4:9 the locusts came some time in the past, whereas in Amos 7:1-3 the locusts are seen in the form of a vision as something yet to come in the not to distant future.

The locusts were formed by Yahweh making it exceptionally threatening (Rudolph 1971:230) and as scholars (Wolff 1977:297; Niehaus 1992:451; Van der Woude 1997:85) have pointed out, the locusts will come at a most vulnerable time for harvesting crops. Locusts were also seen as punishment of Yahweh as he once punished the Egyptians for not letting his people leave Egypt (Ex $10: 12-15)$. In fact, the wording of Amos 7:2 is almost exactly the same as Exodus 10:12,15 and is also unique to these two books (Paul 1991:228). Now, locusts are a threat to the land, endangering the life of both human beings and animals for as Paul (1991:228) pointed out the phrase עשכב ארץ is the comprehensive term employed to express plant growth necessary for man and animal. Locusts are foreseen in the covenant curses of Deuteronomy 28:38,42 as a punishment for the people when they do not live according to the demands of the covenant. The land, supposed to provide food in abundance according to the promises made about the land, will not yield enough grass or wild growth for the animals or crops to be harvested for human beings. 
In Amos 7:4 there is another reference to the land in a unique form in the book of Amos. Land is refered to as החלק meaning "a portion" (Niehaus 1992:454). It recalls the initial division of the land in the book of Joshua $(14: 4 ; 15: 3 ; 19: 9 ; 22: 25,27)$ after the conquest of the land, as well as the portion or lot of land individual Israelites may claim as their part of the land (Preuss 1995:124; Robinson 1964:98-99; Hammershaimb 1970:110). Although there have been many proposals trying to come to a clearer understanding of this vision, the main thrust of the vision is that because of an extreme heat interpreted as Yahweh's judgement, all underground sources of water will eventually dry up with the result that there will be no springs anymore and ultimately even the land allotted to each Israelite will be devoured by this extreme heat likened to a fire (Wolff 1977:298-299; Jeremias 1995:100). The terrifying heat has a devastating effect not only on the water supply but also on the land and that means total desiccation (Paul 1991:232). If there is no produce from the land, there is no means of existence for the small farmers (Jeremias 1995:100). Once again it is said that the land will turn against its inhabitants, the people to whom the land is given, will suffer because of the land.

\subsubsection{Amos 8:4, 8-9, 11}

The word ארץ is used in Amos 8:4, 8, 9 and 11. As the prophecies are directed to Israel in particular it seems better to interpret referring to the land of Israel rather than to the earth in general (Niehaus 1992:473). The land as a place where justice is expected is a place where the needy are trampled and the poor is done away with (Amos 8:4). It is all about the planned annihilation of the small farmer from his land (Jeremias 1995:116) whereas the conditions of the poor and the needy serve as prerequisite for staying in the land. As a result of this misconduct by the people, the land will turn against them in a terrible earthquake and eclipse of the sun. Earthquakes and the eclipse of the sun are seen as Yahweh's anger and punishment for the sins of the people (Jeremias 1995:118-119; Hammershaimb 1970:126; Paul 1991:260; Van der Woude 1997:96; Robinson 1964:102). The land is once again turned against the people living in the land.

According to Amos 8:11 there will be a famine in the landnot for food or a thirst for water, but a famine for the word of Yahweh. There will be this spiritual kind of famine because there will be no word from Yahweh to listen to. Ultimately that means that 
Yahweh himself will be absent from the land so that the anger of Yahweh is manifested in his silence indeed as the climax of Yahweh's judgement against his people (Van Leeuwen 1985:309; Paul 1991:265). The land sustained by the word of Yahweh in all the stipulations, admonitions and even threats, will have to do without it. It reminds one of Deuteronomy 8:3 "that man does not live by bread alone, but man live by everything that proceeds out of the mouth of the Lord".

\subsection{The land lost to Israel in exile}

The land promised and granted to the people to live in will eventually be lost in exile. There are a number of texts hinting at and even overtly said that exile awaits Israel (and Judah).

Sometimes the pending exile is merely hinted at as in 3:11 where it is announced that an unnamed enemy will come and surround the land, or that the houses will be destroyed (3:15), or that the women of Bashan will be cast out and taken away (4:1-3). It is significant that the women will not be raped or killed, they will be driven out of the land that nourishes them underling the importance of the relation between the people and the land they live in (Koch 1983:46-47). The root גלה is used to state the coming exile in no uncertain terms $(5: 27 ; 6: 7)$. The inevitable disaster of exile is announced explicitly in 5:5 in a clever wordplay between Gilgal (הגלגל) and going into exile (גלה) and Bethel (בית-אל) that will be reduced to nothing (לאון). The naming of Gilgal in particular is important in this regard. Wolff (1977:239) noted that Gilgal, a monument to the occupation of the land (Josh 4:20ff), would become a memorial of the expulsion of the land.

Exile will mean total devastation. Commentaries are in agreement that the metaphor used in 3:12 indicates total devastation without any possibility of salvation. The bits and pieces of an animal serve only to produce sufficient evidence of total loss (Wolff 1977:198; Hammerschaimb 1970:61; Deissler 1981:106; Jeremias 1995:41; Paul 1991:119-120; Rudolph 1971:164). The same can be said of the metaphor used in Amos 5:2. The root נפל is used in perfect tense indicating that Israel has fallen, she will not rise again, her collapse is final because it is fatal (Wolff 1977:236; cf also Van der Woude 1997:62; Jeremias 1995:64; Van Leeuwen 1985:179). The fallen Israel described with the image of a virgin will be stretched out, abandoned (נטשטה) on her own land (אדמתה). The land 
once promised and granted to her will also be the place where she will not only suffer humiliation but ultimately the end of her existence as a people (Rudolph 1971:188). The same idea of total devastation is also expressed in Amos' dispute with Amaziah the priest (7:10-17). In an ironic twist it is Amaziah who will die in a foreign land after he wanted Amos to be deported from the land of Israel. Amaziah became in this way the personalised example of the fate of the land and the people living in it (Deissler 1981:126). In Amos 9:8 it is once again said that "the sinful kingdom" will be destroyed from the face of the earth (האדמה) and yet it seems that a door is still open for restoration for it is also said that the house of Jacob will not be totally destroyed.

\section{THE LAND REGAINED IN AMOS 9:11-15}

The book of Amos comes to a close with the well-known prophecy of restoration and salvation. It is a prophecy that is most probably a later (exilic/post-exilic) addition to the book. In verses 11-12 the focus is on the political restoration of the Davidic dynasty, while verses 13-15 focus on the abundance and fertility of the land unheard of hitherto (Am 9:13). The fortunes of the people will be restored (v.14), cities will be rebuilt and they will once again enjoy the fruit of the land. Verse 15 says it explicitly that Israel will be planted in the land (אדמה) never to be taken away again (van Leeuwen 1985:354; Weiser 19:206; Deissler 1981:135). Verse 15 brings together both the future and the past. The people will be planted in their land (אדמתם) opening up a perspective into the future. At the same time they are also reminded that it was Yahweh who initially brought them into the land. The book comes to a close with a powerful statement on the issue of the land.

\section{THE LAND IN THE DOXOLOGIES OF AMOS}

The doxologies in the book of Amos have long been recognised as peculiar to the book and consequently much attention has been paid to them (Paul 1991:152; Wolff 1977:215; Jeremias 1995:56). What is of interest for this contribution is that ארץ is used in each of the three doxologies (Am 4:13; 5:8-9; 9:5-6). In the rest of the book it has been argued that ארץ is used as land, promised, granted, lived in, lost in exile and eventually regained. The interesting fact is that ארץ in the doxologies is used in connection with creation and not in ברא ,יצר 4:13 connection with the tradition of the land. In Amos and עשה are used - all well known words used in creation traditions 
of the Old Testament (Gen 2:7-8, 19; Is 43:1, 7; 45:7). In Amos 5:8-9 the verb עשה occurs again and the statement made clearly reflects creation theology rather than the conquest of the land. The same statement on the land is repeated in 9:8.

If this observation is correct it is also a confirmation of the view that the doxologies in the book must be seen as a distinctive and separate part of the book and most probably a later exilic addition to the book.

\section{THE EARTHQUAKE IN AMOS 1:1 RECONSIDERED}

In the light of the prominent role of the tradition of the land in the book, the earthquake mentioned in Amos 1:1 should perhaps be reconsidered. The reference to the earthquake is interpreted as a historical indication of the time of Amos' appearance as prophet. It serves also as an indication of the length of Amos' preaching activity, probably not more than a year. In the light of the importance of the land in the book and the looming threat of a coming exile due to the conditions in the land, is it not possible that the reference to the land may take on another, additional metaphorical meaning? The reference to the earthquake is perhaps a premonition of what may be expected: turmoil and upheaval in the land even expulsion from the land instead of peace and stability. Mentioning the earthquake right at the beginning may be a subtle reminder that the land is at stake in the prophecies that will follow in the rest of the book.

\section{THE THEME OF THE LAND IN THE BOOK OF THE TWELVE}

The book of Amos is not the only one in the Book of the Twelve dealing with the issue of the land. A quick and cursory view of the rest of the Twelve shows that the land is a theme present in almost every book of the Twelve. Braaten (2003:104-132) has shown how the theme of the land is present in the Book of Hosea (1:2). In Joel the land is stricken with locusts and drought so that there is no joy for mankind anymore. Obadiah is concerned with the reoccupation of the land $(\mathrm{Ob}$ 19-21). It is interesting to note that in the Book of Jonah the first half plays itself out at sea while the second half plays itself out on land. In Micah the earth is called upon to witness against Israel and Judah. In Habakkuk the Babylonians threaten to invade the land. In Zephaniah everything will be swept away from the face of the earth (Zph 1:2). The Book of Malachi closes with a threat that the Lord may come and strike the land with a curse. 


\section{CONCLUSION}

At the end of this investigation the following conclusions can be made:

- Amos is known for his critique on social injustices in society. It is clear from this investigation that the land granted to the people forms the basis of Amos' critique on social injustices in society (cf Koch 1983:50-56; Strydom 1995:398; Strydom 1996:445 and Helberg 1999:571 for similar conclusions). The land is a gift given to them, it is therefore expected that they should live according to the stipulations required of them for a meaningful life in the land. When that did not happen Amos lashes out against the people in severe social criticism threatening them with the loss of the land.

- The hypothesis put at the beginning of this paper is sustained. The tradition of the land is indeed a leitmotiv in the book of Amos. The land is promised and granted to Israel $(2: 9-10 ; 3: 2 ; 3: 9)$, because of the people's disobedience to the covenant the land itself will turn against them $(1: 2 ; 4: 6-13 ; 7: 2-4 ; 8: 8-11)$ and there is the constant threat of losing the land because Israel does not live according to the covenant stipulations of Deuteronomy and therefore Israel stand to lose the land in exile $(3: 11 ; 4: 2-3 ; 5: 2,5,27 ; 6: 7 ; 7: 10-17 ; 9: 8-9)$, but eventually they will regain the land and enjoy the abundance of the land once more (9:13-15).

\section{Consulted literature}

Albertz, R 1994. A History of Israelite Religion in the Old Testament Period. Vol 1: From the Beginnings to the End of the Monarchy. Westminster: John Knox.

Barth, C 1991. God with us. A Theological Introduction to the Old Testament. Michigan: W B Eerdmans.

Braaten, L J 2003. God sows: Hosea's land theme in the book of the Twelve, in: Redditt, P L \& Schart, A (eds) Thematic Threads in the Book of the Twelve. Berlin: Walter de Gruyter (BZAW 325).

Brueggemann, W 1977. The Land. London: SPCK.

Deissler, A 1981. Zwölf Propheten. Hosea Joël Amos. Würzburg: Echter (Neue Echter Bibel).

Diepold, P 1972. Israels Land. Stuttgart: Kohlhammer (Beiträge zur Wissenschaft vom Alten und Neuen Testament 95).

Gunneweg, A H J 1993. Biblische Theologie des Alten Testaments. Eine Religionsgeschichte Israels in biblisch-theologischer Sicht. Stuttgart: Kohlhammer. 
Habel, N C 1995. The Land is mine. Six Biblical Land Ideologies. Minneapolis: Fortress.

Hammerschaimb E 1970. The Book of Amos A Commentary. Oxford: Basil Blackwell.

Helberg, J L 1999. Die betekenis van die konsep land in die slot van die boek Amos. In die Skriflig 33(2), 273-289.

-, 1999. Wat sê die boek Amos en Handelinge 15:15-17 oor die/'n beloofde land? In die Skriflig 33(4), 567-583.

Jeremias, J J 1995. Das Buch Amos. Göttingen: Vandenhoeck \& Ruprecht (ATD).

Koch, K 1983. The Prophets I. Philadelphia: Fortress.

LaCocque, A 1996. The Land in "D" and "P", in: Augustin, M \& Schunck, K D (Hrsg), "Dort ziehen Schiffe dahin..." Collected Communications to the XIVth Congress of the International Organization for the Study of the Old Testament, Paris, 1992. Frankfurt am Main: Peter Lang, 91-100.

Niehaus, J 1992. Amos, in: McComiskey, T E (ed) The Minor Prophets, An Exegetical and Expository Commentary, Hosea, Joel and Amos. Volume 1. Grand Rapids: Baker Book House.

Noort, Ed, 1993. Een plek om te zijn. Over de theologie van het land aan de hand van Jozua 8:30-35. Kampen: Kok.

-, 1998. Land and reconciliation, land claims and loss of land. NGTT XXXIX (1\&2) Maart en Junie, 12-28.

Paul, S M 1991. Amos. A Commentary on the Book of Amos. Minneapolis: Fortress (Hermeneia).

Preuss, H D 1991. Old Testament Theology, Volume I. Louisville: Westminster John Knox.

Rendtorff, R 2001. Theologie des Alten Testaments, Ein Kanonischer Entwurf. Band 2: Thematische Entfaltung. Neukirchen-Vluyn: Neukirchener.

Rudolph, W 1971. Joel - Amos - Obadja - Jona. Gerd Mohn: Gütersloher (KAT).

Snyman, S D 1994. A Note on Ashdod and Egypt in Amos iii 9. VT 44, 559562.

Strydom, J G 1995. Redistribution of the Land: The eighth century in Israel, the twentieth century in South Africa. OTE 8(3), 398-413.

-, 1996. Sosiale geregtigheid by die profeet Amos: Die landsbelofte as vertrekpunt. HTS 52(2\&3), 431-448.

Van der Woude 1997. Amos - Obadja - Jona. Een praktische bijbelverklaring. Kampen: Kok (Tekst en Toelichting).

Van Leeuwen, C 1985. Amos. Nijkerk: Callenbach (POT).

Von Rad, G 1975. Old Testament Theology, Vol I. London: SCM.

-, 1984. The Problem of the Hexateuch and other Essays. London: SCM. 
-, 1984. The promised Land and Yahweh's Land in the Hexateuch, in: Von Rad G, The Problem of the Hexateuch and other Essays. London: SCM, 79-93.

Weinfeld, M 1992. The promise of the land: The inheritance of the Land of Canaan by the Israelites. Berkeley: University of California Press.

Weiser, A 1974. Das Buch der zwölf kleinen Propheten I. Göttingen: Vandenhoeck \& Ruprecht (ATD 24).

Westermann, C 1978. Theologie des Alten Testaments in Grundzügen. Göttingen: Vandenhoeck \& Ruprecht (ATD Ergänzungsreihe 6).

Wolff, H W 1977. Joel and Amos. A Commentary on the books of Joel and Amos. Philadelphia: Fortress (Semeia).

Wright, C J H 1983. Living as the People of God. The relevance of Old Testament Ethics. Leicester: Inter-Varsity Press.

-, 1990. God's people in God's Land. Grand Rapids: Eerdmans.

Zenger, E 1993. Deinen Nachkommen gebe ich dieses Land...(Gen 12,7) Überlegungen zum christlichen Umgang mit den Landverheissungstexten des Ersten Testaments, in: Hahn, F, Hossfeld, F L, Jorissen, H \& Neuwirth, A (Hrsg), Zion - Ort der Begegnung. Festschrift für Laurentius Klein zur Vollendung des 65. Lebensjahres. Bodenheim: Athenäum (Bonner Biblische Beiträge 90).

Zimmerli, W 1976. The Old Testament and the World. London: SPCK.

-, 1978. Old Testament Theology in Outline. Edinburgh: T \& T Clark.

-, 1985. The Land in the Pre-exilic and early post-exilic Prophets, in: Butler, J $\mathrm{T}$, Conrad, E W \& Ollenburger, B C (eds). Understanding the Word, Essays in Honor of $B W$ Anderson, Sheffield: JSOT Press, 247-264 (JSOT 37). 